\title{
Zooplankton of the Paraguay River : a comparison between sections and hydrological phases
}

\author{
S.M. Frutos ${ }^{1,2 *}$, A.S.G. Poi de Neiff ${ }^{1,2}$, J.J. Neiff ${ }^{1}$ \\ ${ }^{1}$ Centro de Ecología Aplicada del Litoral (CONICET). C.C. 291, 3400 Corrientes, Argentina. \\ ${ }^{2}$ Facultad de Ciencias Exactas, Físicas y Naturales. Universidad Nacional del Nordeste. Av. Libertad 5500, 3400 Corrientes, Argentina.
}

\begin{abstract}
Changes in the abundance, species richness and species diversity of zooplankton were studied in the Paraguay River. Fifty-nine sites were studied at two hydrological phases between Porto Cáceres (16 $\left.03^{\circ} \mathrm{S}-26^{\circ} 23^{\prime} \mathrm{W}\right)$ and the confluence with the Paraná (Argentine, 26 $6^{\circ} 3^{\prime}$ S-58 $23^{\prime} \mathrm{W}$ ), representing a distance of $2270 \mathrm{~km}$. Zooplankton densities varied between 1 and 60 ind.1 ${ }^{-1}$ at high water and between 11 and 100 ind. $1^{-1}$ at low water. Multiple regression analysis revealed that the hydrological phase explained $64 \%$ of the variability in zooplankton density. Surveys found 196 taxa in the Paraguay River (including both the main course and its floodplain). The greater species richness was registered in the upper section. There were significant differences in the species richness and species diversity of Rotifera (Monogononta) between hydrological phases. In the main channel, the hydrological phase explained $54 \%$ of variability in species richness, whereas water temperature and electric conductivity explained less than $22 \%$ of the variability in species diversity. Rotifera was the most abundant group in both study periods. Despite the total number of species registered in the main channel, only six planktonic genera dominated the zooplankton assemblage (Polyarthra, Synchaeta, Filinia, Keratella and Lecane). The most abundant cladocerans belonged to Bosminidae (Bosminopsis sp.) and the dominant copepods were in the nauplii and juveniles stages. A longitudinal pattern in dominant taxa was not defined at high water. At low water, three species-site groups were separated in relation to environmental variables. The pulsing of the river determines the degree of connectivity with the floodplain and local features had a greater effect on zooplankton assemblages than large-scale landscape patterns.
\end{abstract}

Keywords : Paraguay River, hydrologic phases, zooplankton abundance, zooplankton composition

\section{Introduction}

The question of how the structure and function of communities change from headwaters to river mouths in relation to the abiotic environment remains a central issue in the study of the biology of running water systems (Vannote et al. 1980, Statzner \& Higler 1985, Minshall et al. 1985, Meyer \& Edwards 1990, Wiley et al. 1990, Petts \& Calow 1996, Miranda \& Raborn 2000, Maamri et al. 2005). Several investigations of river zooplankton have shown that abundance and species richness increase downstream though the information available for large South American Rivers is limited (José de Paggi 1980, Saunders \& Lewis 1989, Vasquez \& Rey 1989).

\footnotetext{
* Corresponding author : E-mail : margaritafrutos_587 @yahoo.com.ar
}

The Paraguay River is a pristine running water system which is scarcely disturbed by human activities. The main channel is largely unregulated, with one dam located on a secondary tributary. Furthermore, it has peculiarities that distinguish it from other streams the upper section drains the Pantanal (a great wetland of $138,000 \mathrm{~km}^{2}$ ) and the lower section receives Andean sediments through the Bermejo River $100 \mathrm{~km}$ before its confluence with the Paraná River. Current knowledge of the zooplankton in the main channel of the Paraguay River is limited to the results of one study in the lower section of the river near its confluence with the Paraná River (Bonetto \& Corrales de Jacobo 1985). Other studies have been conducted in the floodplains of the Upper Paraguay River and its major tributaries (Reid \& Moreno 1990, Bezerra et al. 1996, Bonecker et al. 1996, Espíndola et al. 1996, Neves et al. 2003). Most of the information concerning zooplankton has been obtained from the floodplain and the main channel of the Paraná River (Corrales 
1979, José de Paggi 1980, Paggi 1980, Paggi \& José de Paggi 1990, Frutos 1993, 1996, 1998, Lansac Tôha et al. 2004). Although many factors influence river plankton, variations in the abundance and species composition have been attributed primarily to hydrological regimes (Bonetto 1986, Neiff 1990, Paggi \& José de Paggi 1990, Welcomme 1992, Zalocar de Domitrovic 2002, Lansac Tôha et al. 2004). This study was carried out in 59 sites along the Paraguay River and its floodplain during high and low water phases in order to asses the influence of water level and environmental factors on zooplankton abundance, species richness and diversity. In this study, we tested the hypotheses that (a) the longitudinal distribution of the zooplankton has a different pattern than that in other large rivers ; and (b) the alternance of high and low water phases is a major factor determining the composition and abundance of zooplankton.

\section{Study Area}

The Paraguay River, with a catchment area of $2.6 \times 10^{6}$ $\mathrm{km}^{2}$ and a length of $2550 \mathrm{~km}$, is the Paraná River's largest tributary. Flooding in this river is distinctly seasonal, although the high water phase of the river may be delayed by 4 to 6 months after the summer rains due to the slow passage of floodwaters through the Pantanal. During the rainy period, the lake and tributary rivers are connected toward the main course of the Upper Paraguay River. In the low water phase, some lakes and lagoons are isolated and their surfaces can be reduced by a factor of four or more in years of drought (Hamilton et al. 1997). The Upper Paraguay River flows between the rise in the Matto Grosso (Brazil) and the Apa River confluence (Fig. 1). The Cuiabá, Taquarí, Negro and Miranda Rivers are the major tributaries in the Upper Paraguay River. Downstream of Corumba, the mean slope is $3 \mathrm{~cm} \mathrm{~km}^{-1}$ and the river is moderately sinuous with occasional islands (Hamilton et al. 1997). Due to a weak slope the Pantanal is considered to delay the flow of water, nutrients and sediments (Adamoli \& Pott 1999).

The section of the Paraguay River between the Apa River, the first tributary not influenced by the Pantanal, and the confluence with the Paraná River is the Lower Paraguay (Neiff 1990). This section has a low sinuosity (1.45-1.50) and slope $\left(0.035 \mathrm{~m} \mathrm{~km}^{-1}\right)$, and its floodplain extends from $2.4 \mathrm{~km}$ to $17.8 \mathrm{~km}$ in the right bank and between 1.8 and $7.2 \mathrm{~km}$ in the left bank (Orfeo 1995). The high suspended load of the Bermejo River (ranging from 3 to more than $10 \mathrm{~g} \mathrm{liter}^{-1}$ ), originates from the erosion of the Andes mountains, and strongly influences the suspended load of the Lower Paraguay, which increases from 100 to $600 \mathrm{mg} \mathrm{liter}^{-1}$ after their confluence (Drago

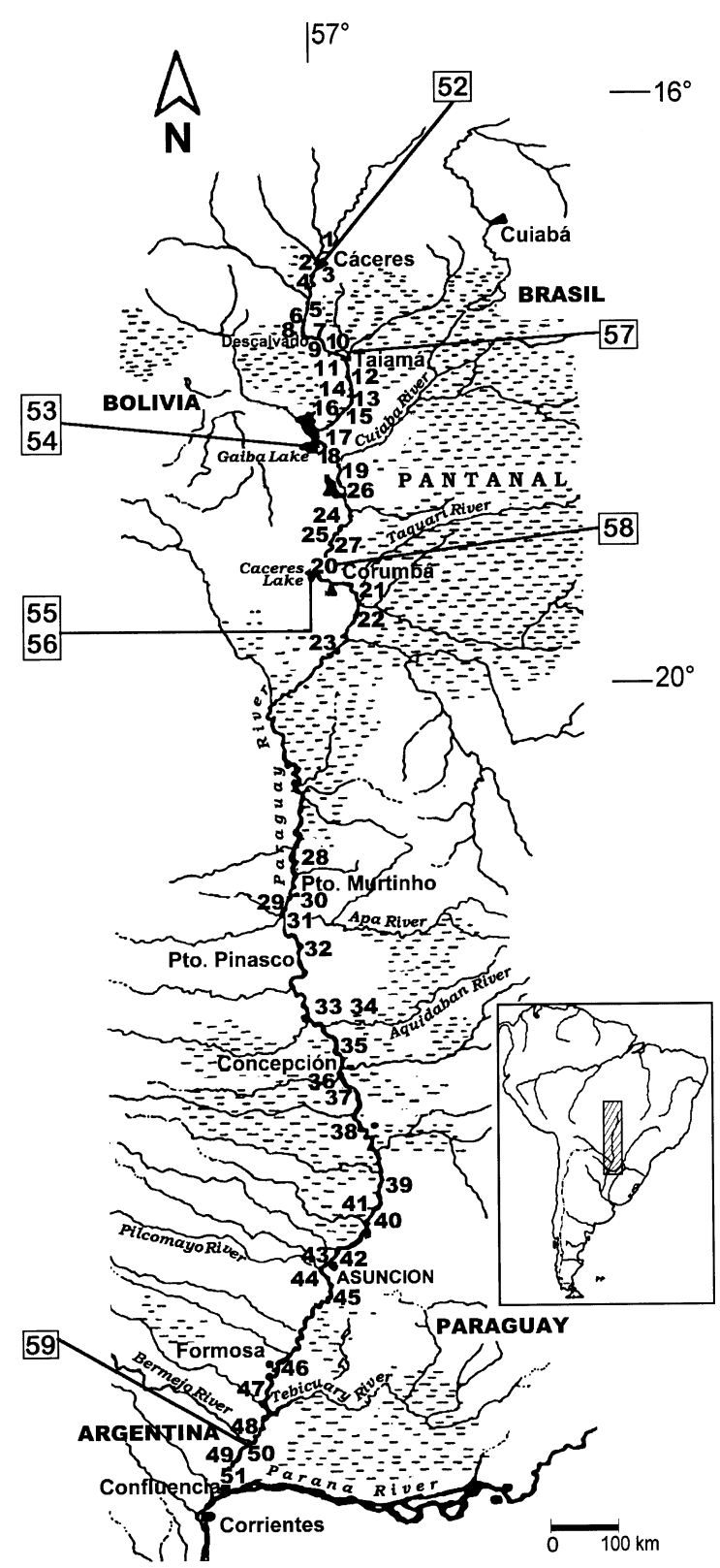

Fig. 1. Sampling sites of Paraguay River. Main course in the upper section (sites : 1 -37) from Porto Cáceres $\left(16^{\circ} 04^{\prime} \mathrm{S}-57^{\circ} 42^{\prime} \mathrm{W}\right)$ to Apa River $\left(22^{\circ} 03^{\prime} \mathrm{S}-58^{\circ} 00^{\prime} \mathrm{W}\right)$ and in the lower section (sites 38 51) from this site to the confluence with the Paraná River (26 53'S-58 $23^{\circ} \mathrm{W}$ ). Floodplain of Paraguay River (sites 52-59).

1990). Below the confluence with the Bermejo, conductivity increases to $550 \mu \mathrm{S} \mathrm{cm}^{-1}$, $\mathrm{pH}$ values reach 8.2 , and water temperature fluctuates between 17 and $30^{\circ} \mathrm{C}$ (Bonetto 1986). 


\section{Methods}

Fifty-nine sites were sampled in the Paraguay River between Porto Cáceres $\left(16^{\circ} 03^{\prime} \mathrm{S}-26^{\circ} 23^{\prime} \mathrm{W}\right)$ and the confluence with the Paraná River (Argentine, 57 13 'S$58^{\circ} 23^{\prime} \mathrm{W}$ ). Of the $2270 \mathrm{~km}$ in this stretch of river, 1344 $\mathrm{km}$ belonged to the Upper and $925 \mathrm{~km}$ to the Lower Paraguay. Thus there were more sampling sites in the first section (31) than in the last section (20 ; Fig. 1). To take into account the position along the latitudinal gradient and the distance to the most important port, we selected sites that were more accessible by land or by water. However, some of these sites were sampled only at low water or high water because of difficulties in accessing the sites. Sites downstream of the main tributaries of the upper section of the river were mainly sampled during low water because water from several tributaries converge at these sites points and consequently provides information about sites often inaccessible.

At high water, zooplankton collections were made between June 20 and July 12, 1995, whereas low water samples were collected between December 5 and December 13, 1995. At both sites (the main course and floodplain), 100 litres of subsurface water were collected and filtered through a plankton net of $53 \mu \mathrm{m}$ mesh size. Samples were preserved with a $4 \%$ formaldehyde solution. Sub-samples were counted until at least 100 individuals of the most abundant taxa were recorded or until the entire samples had been examined. Abundance was expressed as ind. $\mathrm{l}^{-1}$ and species diversity (H') of the dominant group (Rotifera, Monogononta) was estimated using the Shannon-Weaver index (Shannon 1963). The similarity between phases was estimated from the quantitative Bray-Curtis index (1957),

$$
C_{N}=\frac{2 j N}{a N+b N}
$$

where :

$a N=$ number of individual sampled in habitat $a$;

$b N=$ the same in habitat $b$;

${ }_{J} N=$ the sum of the lesser values for the species common to both habitat.

Physical and chemical data were taken at each site. Electrical conductivity, dissolved oxygen, and $\mathrm{pH}$ were recorded using Checkmate 90 (Corning) conductivity meters, Oxi-330 portable oxygen meters (WTW), and pH meter-330s (WTW), respectively. Transparence was measured with a Secchi disk. Suspended solids were quantified using instantaneous water samples $(500 \mathrm{ml})$ at
$0.5 \mathrm{~m}$ below the water surface which were filtered through cellulose acetate disks of $0.45 \mu \mathrm{m}$ pore size.

A nonparametric analysis of variance (Mann-Whitney $U$ test, Zar 1984) was used to test for significant differences in zooplankton density, species richness and diversity between hydrological phases (high and low water). To evaluate differences in abundance and diversity between the upper and lower sections of the river in each hydrological phase, we used a non- parametric KruskalWallis test and a Dunn comparison for multiple tests. The influence of abiotic variables (hydrological phase, sampling site, seasonality, water temperature, specific conductivity, suspended solids and $\mathrm{pH}$ ) on zooplankton abundance, species richness and diversity was analyzed using a forward stepwise multiple regression analysis after normalization of the data $(\log (x+1))$. We used categorical variables for hydrological phases and the correlated number of days for seasonality. Detrended Correspondence Analysis (DECORANA) was used to identify gradients in the community structure of zooplankton in high and low water phases using the PC-ORD multivariate statistical package (version 3.0, 1997, McCune \& Mefford). Environmental variables, with the exception of $\mathrm{pH}$, were log-transformed prior to statistical analysis to normalize and stabilize variances. Independent variables used to identify environmental predictors were used in Multiple Regression Analysis (stepwise) with DCA axes 1 and 2 (Stat Graphic Plus, version 5.1).

\section{Results}

In the upper section, water temperature ranged between 28.9 and $32.5^{\circ} \mathrm{C}$ in December and between 22.5 and $26.3^{\circ} \mathrm{C}$ in the June to July sampling period. $\mathrm{pH}$ varied from slightly acidic to neutral throughout the study period, while the specific conductance fluctuated between 28 and $90 \mu \mathrm{S} \mathrm{cm}^{-1}$, and the concentration of suspended solids varied between 10 and $94 \mathrm{mg} \mathrm{l}^{-1}$ depending on the sampling date (Table 1). In the lower section there was a major seasonal variation in the water temperature (temperatures differed by $10^{\circ} \mathrm{C}$ ) and the specific conductance increased up to $190 \mu \mathrm{S} \mathrm{cm}^{-1}$ during low water (Table 1). In this phase, the concentration of suspended solids increased to $257 \mathrm{mgl}^{-1}$ and $\mathrm{pH}$ reached 7.9 after the confluence with the Bermejo River which discharged into the Paraguay River along its right bank. The concentration of dissolved oxygen at the study sites ranged from 0.2 to $8.4 \mathrm{mg} \mathrm{l}^{-1}$ (Table 1). Low concentrations of dissolved oxygen were observed at either high or low water depending on the sampling sites, although the oxygen depletion was more pronounced in the upper section. In the floodplain, the oxygen concentration varied widely in 
Table 1. Physical and chemical variables of Paraguay River. $\mathrm{N}$ : data number for each variable. $\mathrm{R}$ : variation range. $X$ : arithmetic mean . C.V. : variation coefficient.

\begin{tabular}{|c|c|c|c|c|c|c|}
\hline $\begin{array}{l}\text { Paraguay River } \\
\text { Sections }\end{array}$ & $\begin{array}{c}\text { Temperature } \\
\left({ }^{\circ} \mathrm{C}\right)\end{array}$ & $\begin{array}{l}\text { Secchi } \\
\quad(\mathrm{m})\end{array}$ & $\begin{array}{l}\text { Conductivity } \\
\left(\mu \mathrm{S} \mathrm{cm} \mathbf{c m}^{-1}\right)\end{array}$ & $\begin{array}{c}\text { Dissolved } \\
\text { Oxygen } \\
\left(\mathrm{mg} \mathrm{l}^{-1}\right)\end{array}$ & $\mathbf{p H}$ & $\begin{array}{c}\text { Suspended } \\
\text { solids } \\
\left(\mathrm{mg} \mathrm{l}^{-1}\right)\end{array}$ \\
\hline \multicolumn{7}{|c|}{ High water } \\
\hline $\begin{array}{l}\text { Upper } \\
\text { section }\end{array}$ & $\begin{array}{l}\mathrm{N}: 22 \\
\mathrm{R}: 22.5-26.3 \\
X: 24.6 \\
\text { C.V. }: 0.04\end{array}$ & $\begin{array}{l}\mathrm{N}: 20 \\
\mathrm{R}: 0.3-1.3 \\
X: 0.6 \\
\text { C.V. }: 0.5\end{array}$ & $\begin{array}{l}\mathrm{N}: 19 \\
\mathrm{R}: 28-51 \\
X: 40.4 \\
\text { C.V. }: 0.16\end{array}$ & $\begin{array}{l}\mathrm{N}: 20 \\
\mathrm{R}: 1.7-8.4 \\
X: 6.3 \\
\text { C.V. }: 0.26\end{array}$ & $\begin{array}{l}\mathrm{N}: 20 \\
\mathrm{R}: 6.3-7.1 \\
X: 6.7 \\
\text { C.V. }: 0.03\end{array}$ & $\begin{array}{l}\mathrm{N}: 20 \\
\mathrm{R}: 10-52 \\
X: 19 \\
\text { C.V. : } 0.52\end{array}$ \\
\hline $\begin{array}{l}\text { Lower } \\
\text { section }\end{array}$ & $\begin{array}{l}\mathrm{N}: 9 \\
\mathrm{R}: 18-23.4 \\
X: 20.22 \\
\text { C.V. }: 0.07\end{array}$ & $\begin{array}{l}\mathrm{N}: 7 \\
\mathrm{R}: 0.26-0.91 \\
X: 0.68 \\
\text { C.V. }: 0.33\end{array}$ & $\begin{array}{l}\mathrm{N}: 10 \\
\mathrm{R}: 71-100 \\
X: 85 \\
\text { C.V. }: 0.12\end{array}$ & $\begin{array}{l}\mathrm{N}: 10 \\
\mathrm{R}: 4.4-7.2 \\
X: 5.87 \\
\text { C.V. }: 0.14\end{array}$ & $\begin{array}{l}\mathrm{N}: 10 \\
\mathrm{R}: 6.3-6.9 \\
X: 6.5 \\
\text { C.V. }: 0.03\end{array}$ & $\begin{array}{l}\mathrm{N}: 9 \\
\mathrm{R}: 6-171 \\
X: 50.9 \\
\text { C.V. }: 1.09\end{array}$ \\
\hline \multicolumn{7}{|c|}{ Low water } \\
\hline $\begin{array}{l}\text { Upper } \\
\text { section }\end{array}$ & $\begin{array}{l}\mathrm{N}: 27 \\
\mathrm{R}: 28.9-32.5 \\
X: 30.6 \\
\text { C.V. }: 0.06\end{array}$ & $\begin{array}{l}\mathrm{N}: 27 \\
\mathrm{R}: 0.09-0.32 \\
X: 0.23 \\
\text { C.V. }: 0.48\end{array}$ & $\begin{array}{l}\mathrm{N}: 27 \\
\mathrm{R}: 50-90 \\
X: 54.4 \\
\text { C.V. }: 0.43\end{array}$ & $\begin{array}{l}\mathrm{N}: 23 \\
\mathrm{R}: 0.2-5.8 \\
X: 4.4 \\
\text { C.V. }: 0.42\end{array}$ & $\begin{array}{l}\mathrm{N}: 28 \\
\mathrm{R}: 5.8-7.4 \\
X: 6.3 \\
\text { C.V. }: 0.07\end{array}$ & $\begin{array}{l}\mathrm{N}: 18 \\
\mathrm{R}: 24-94 \\
X: 57.6 \\
\text { C.V. }: 0.4\end{array}$ \\
\hline $\begin{array}{l}\text { Lower } \\
\text { section }\end{array}$ & $\begin{array}{l}\mathrm{N}: 16 \\
\mathrm{R}: 27-32 \\
X: 30 \\
\text { C.V. }: 0.05\end{array}$ & $\begin{array}{l}\mathrm{N}: 16 \\
\mathrm{R}: 0.11-0.30 \\
X: 0.24 \\
\text { C.V. }: 0.20\end{array}$ & $\begin{array}{l}\mathrm{N}: 16 \\
\mathrm{R}: 91-190 \\
X: 107 \\
\text { C.V. : } 0.26\end{array}$ & $\begin{array}{l}\mathrm{N}: 6 \\
\mathrm{R}: 6.5-6.7 \\
X: 6.6 \\
\text { C.V. : } 0.01\end{array}$ & $\begin{array}{l}\mathrm{N}: 17 \\
\mathrm{R}: 6.8-7.9 \\
X: 7.6 \\
\text { C.V. }: 0.04\end{array}$ & $\begin{array}{l}\mathrm{N}: 17 \\
\mathrm{R}: 26-257 \\
X: 82.5 \\
\text { C.V.: } 0.75\end{array}$ \\
\hline
\end{tabular}

Table 2. Physical and chemical variables of Paraguay River floodplain. n.a : not available.

\begin{tabular}{|c|c|c|c|c|c|c|c|}
\hline $\begin{array}{l}\text { Floodplain } \\
\text { sites }\end{array}$ & $\begin{array}{c}\text { Temperature } \\
\left({ }^{\circ} \mathrm{C}\right)\end{array}$ & $\begin{array}{c}\text { Secchi } \\
\text { (m) }\end{array}$ & $\begin{array}{l}\text { Conductivity } \\
\left(\mu \mathrm{S} \mathrm{cm}{ }^{-1}\right)\end{array}$ & $\begin{array}{c}\text { Dissolved } \\
\text { oxygen } \\
\left(\mathrm{mg} \mathrm{l}^{-1}\right)\end{array}$ & $\begin{array}{c}\text { Oxygen } \\
\text { (\% saturation) }\end{array}$ & pH & $\begin{array}{c}\text { Suspended } \\
\text { solids } \\
\left(\mathrm{mg} \mathrm{l}^{-1}\right)\end{array}$ \\
\hline \multicolumn{8}{|c|}{ High water } \\
\hline 52 & 22.6 & 0.35 & 31 & 7.0 & 88 & 6.3 & 14 \\
\hline 53 & 24.1 & 0.65 & 44 & 7.7 & 94 & 7.1 & 15 \\
\hline 54 & $24.8-25$ & 1.0 & $65-79$ & $0-2.7$ & $0-33$ & $6.5-6.7$ & $13-19$ \\
\hline 55 & 24 & 0.90 & 111 & n.a. & n.a. & 6.7 & 21 \\
\hline 58 & 20 & 0.60 & 78 & 6.2 & 70 & 6.5 & 24 \\
\hline \multicolumn{8}{|c|}{ Low water } \\
\hline 52 & 33.6 & 0.27 & 50 & 4.7 & 66 & 6.3 & 24 \\
\hline 53 & 29 & 0.20 & n.a. & n.a. & n.a. & n.a. & 13 \\
\hline 54 & 29.7 & 0.11 & 120 & 4.8 & 63 & 6.3 & 83 \\
\hline 55 & 30.6 & 0.11 & 110 & 5.5 & 74 & 6.4 & 83 \\
\hline 56 & 29.9 & 0.12 & 52 & 5.9 & 78 & 6.2 & 98 \\
\hline 57 & 30.9 & 0.21 & 42 & 5 & 67 & 5.8 & 29 \\
\hline 59 & 28 & 0.07 & 190 & 6.6 & 85 & 7.8 & 222 \\
\hline
\end{tabular}


Table 3. Zooplankton abundance, species richness and species diversity of Rotifera (Monogononta) in both sections of Paraguay River. $\mathrm{n}$ : sampling number.R : range. $X$ : arithmetic mean. C.V. :variation coefficient.

\begin{tabular}{|c|c|c|c|c|c|c|c|c|}
\hline \multirow{3}{*}{$\begin{array}{l}\text { Paraguay } \\
\text { River } \\
\text { Sections }\end{array}$} & \multicolumn{4}{|c|}{ High water } & \multicolumn{4}{|c|}{ Low water } \\
\hline & \multicolumn{8}{|c|}{ Abundance (ind..$^{-1}$ ) } \\
\hline & $\mathrm{n}$ & $\mathrm{R}$ & $\mathrm{X}$ & C.V. $(\%)$ & $\mathrm{n}$ & $\mathrm{R}$ & $\mathrm{X}$ & C.V. $(\%)$ \\
\hline Upper & 22 & $1-60$ & 10 & 123 & 18 & $11-98$ & 43 & 62 \\
\hline Lower & 9 & $2-16$ & 8 & 51 & 17 & $30-101$ & 61 & 29 \\
\hline \multicolumn{9}{|c|}{ Species richness } \\
\hline Upper & 22 & $3-16$ & 9 & 45 & 18 & $8-27$ & 18 & 30 \\
\hline Lower & 9 & $6-13$ & 7 & 41 & 17 & $7-22$ & 15 & 28 \\
\hline \multicolumn{9}{|c|}{ Species diversity (Rotifera, Monogononta) } \\
\hline Upper & 22 & $0.27-3.55$ & 2.42 & 33 & 18 & $2.16-4.17$ & 3.44 & 14 \\
\hline Lower & 9 & $1.55-3$ & 2.12 & 23 & 17 & $2-3.98$ & 2.82 & 17 \\
\hline
\end{tabular}

both hydrological phases and anoxic water was registered during high water (site 54, Table 2) in areas with a dense cover of macrophytes. Site 59 showed the lowest transparency, the highest concentration of suspended solids and the highest conductivity (Table 2). The highest observed $\mathrm{pH}$ value was also recorded at this site.

\section{Zooplankton in the main channel}

The mean abundance of total zooplankton, species richness and specific diversity within each section of the river in the two hydrological phases are depicted in Table 3. The high coefficients of variation estimated for these variables indicate high site heterogeneity, especially at high water.

\section{Comparison between hydrological phases}

At high water, zooplankton density recorded at each site was less than 15 ind..$^{-1}$ except in sites 1 and 3 from the upper section (Fig. 2). At low water, highest densities (85 to 100 ind. $^{-1}$ ) were registered in both, the upper (sites 27 , 28,29 ) and lower sections (sites 41, 46 and 47, Fig. 2). Abundance was significantly higher during the low water phase than during the high water phase (M-W test, $\mathrm{U}_{35,31}$ $=38.00 ; \mathrm{p}<0.0001)$. Stepwise multiple regression analysis revealed that the hydrological phase explained $64 \%$ of the variability in zooplankton abundance while seasonality explained less than $4 \%$ (Table 4 ). Rotifera was the most abundant taxa (Figs. 3 and 4 ) and the only taxonomic group present in the sites 4, 34 and 48 in high water and 36 and 48 in low water. In the upper section (Fig. 2), the abundance of Copepoda nauplii stages and Protozoa (Testacea) was higher during high water phase in sites 1 and 3 respectively. The number of taxa recorded per site on different hydrological phases (Figs. 4 and 5)

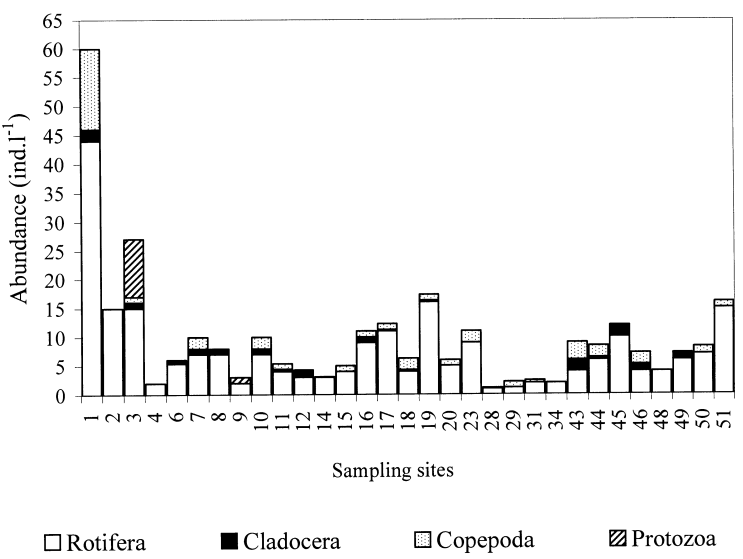

Fig. 2. Abundance of zooplankton in upper and lower sections of Paraguay River at high water.

ranged from 3 to 27 , whereas species diversity varied between 0.27 and 4.17 bits. Species richness (M-W test, $\left.\mathrm{U}_{35,31}=85.00 ; \mathrm{p}<0.0001\right)$ and species diversity (M-W test, $\left.\mathrm{U}_{35,31}=213.50 ; \mathrm{p}<0.0001\right)$ were significantly higher in the low water phase than during high water. The regression analysis showed that hydrological phase explained $53 \%$ of the variability in species richness in the main course (Table 4) and that water temperature and electric conductivity explained less than $22 \%$ of the variability in species diversity.

A total of 187 taxa suprageneric were collected from 59 sites in the main course during the period of this study, consisting of Rotifera (154), Cladocera (21), Copepoda (8) and Protozoa (Testacea : 4). Only 32 taxa occurred exclusively during high water, 83 were found exclusively during the low water phase, and 72 were found in both phases. In the dominant group, a total of 14 families was 


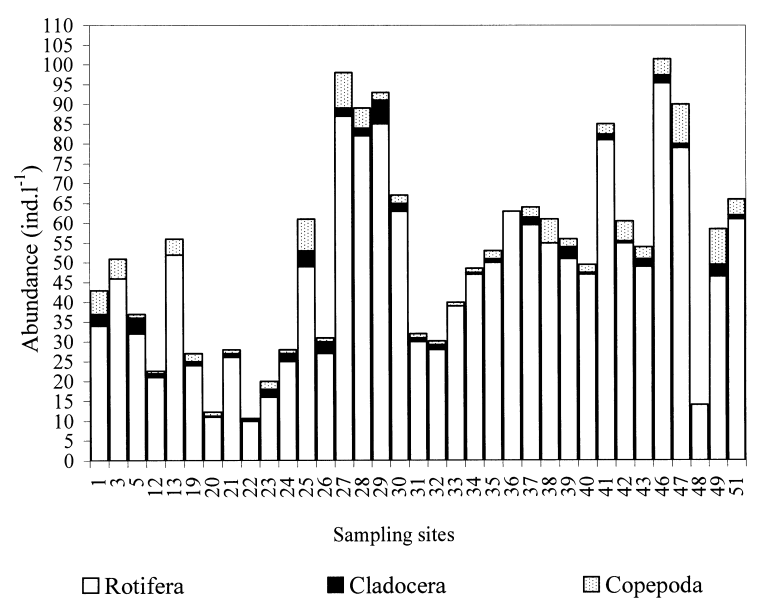

Fig. 3. Abundance of zooplankton in the upper and lower sections of Paraguay River at low water.

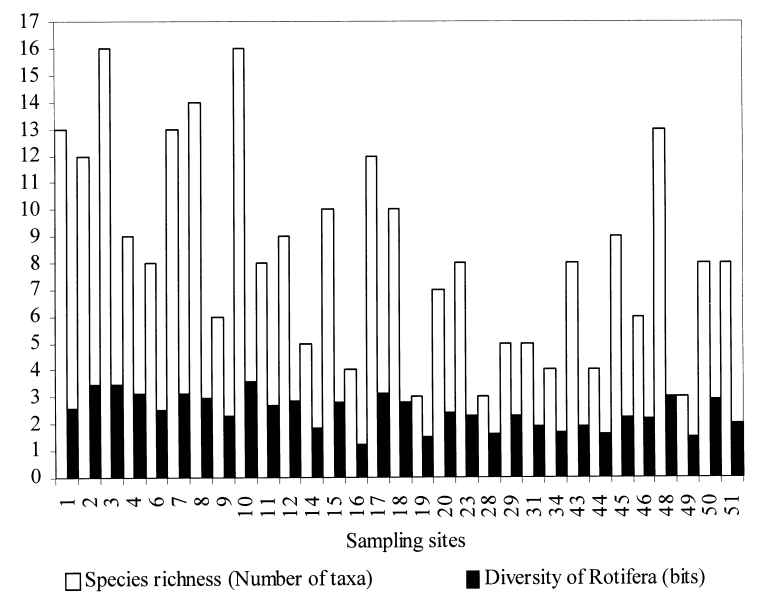

Fig. 4 Species richness (Number of taxa) and diversity of Rotifera, Monogononta (bits) in the main course of Paraguay River at high water.

recorded, mainly Brachionidae (24 species), Lecanidae (35 species), and Trichocercidae (22 species). Despite the total number of species registered in the main channel, only six planktonic genera dominated the zooplankton assemblage (Polyarthra, Synchaeta, Filinia, Keratella and Lecane). The most abundant cladocerans belonged to Bosminidae (Bosminopsis sp. Table 6) and the dominant copepods were in the nauplii and juvenile stages.

\section{Comparison between sections}

No significant differences were found when KruskalWallis and Dunn multiple comparisons tests were used to

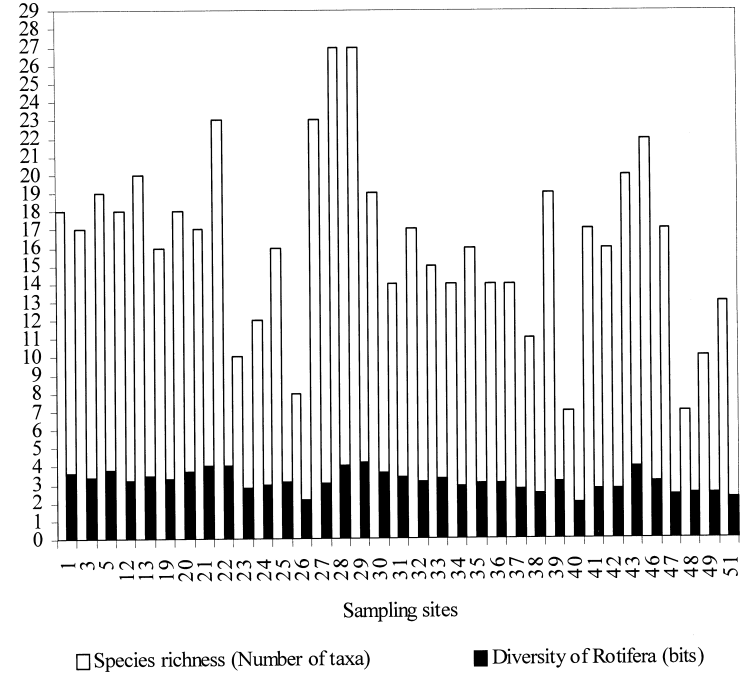

Fig. 5. Species richness (Number of taxa) and diversity of Rotifera, Monogononta (bits) in the main course of Paraguay River at low water.

Table 4. Multiple regression analysis (stepwise) between abundance, species richness, species diversity (Rotifera, Monogononta) and environmental variables of Paraguay River.

\begin{tabular}{|c|c|c|c|}
\hline Variables & Estimate & $\begin{array}{c}\text { Standard } \\
\text { error }\end{array}$ & $\begin{array}{c}\mathbf{r}^{2} \\
\text { ajusted } \\
(\%)\end{array}$ \\
\hline \multicolumn{4}{|c|}{ Abundance (ind. $\mathrm{I}^{-1}$ ) } \\
\hline Cons & 0.384572 & 0.247285 & 0.00 \\
\hline $\begin{array}{l}\text { Hydrological } \\
\text { phases }\end{array}$ & 4.68815 & 1.47835 & 63.98 \\
\hline Seasonality & -0.0236705 & 0.009131 & 67.42 \\
\hline \multicolumn{4}{|c|}{ Species richness } \\
\hline$\overline{\text { Cons }}$ & 0.220859 & 0.12 & 0.00 \\
\hline $\begin{array}{l}\text { Hydrological } \\
\text { phases }\end{array}$ & 0.488541 & 0.0687624 & 53.50 \\
\hline
\end{tabular}

Species diversity (Rotifera, Monogononta)

\begin{tabular}{lccc}
\hline Constant & 0.341876 & 0.0773341 & 0.00 \\
Temperature & 0.0109739 & 0.00282513 & 16.77 \\
Conductivity & -0.000744816 & 0.000350331 & 22.24 \\
\hline
\end{tabular}

compared abundances and number of species per site between sections ( $p>0.05$ ). Conversely, at low water species diversity was significantly higher in the upper section $(\mathrm{p}<0.05)$ than in the lower section. At high water, DCA analysis and regression of the resulting principal axes indicated no significant relationship between the species-site and environmental variables. At low water, DCA analysis with 0.94 of inertia (total variance) indi- 
cated the relative importance of the axes. Eigenvalues 1 and 2 were 0.53 and 0.19 , respectively, while the respective lengths of the gradients were 2.21 and 1.79SD. Three species-site groups were separated (Fig. 8). In the first group, Polyarthra, Filinia and Trichocerca were associated with some sites of the upper section. At the extreme of axis 1, two groups of species were related to the lower section : K. americana and Lecane proiecta (second group) and $K$. cochlearis (third group) were associated with some sites downstream of the Pilcomayo and Bermejo Rivers. Regressions of DCA axes 1 and 2 with environmental variables indicated that $\mathrm{pH}$ and the concentration of suspended solids explained 61 and $18 \%$ of the variability in the species-sites associations respectively (Table 5).

Table 5. Multiple regression analysis (stepwise) between axes 1 and 2 of CDA and environmental variables of Paraguay River at low water.

\begin{tabular}{|c|c|c|c|c|}
\hline \multicolumn{5}{|c|}{ Low water } \\
\hline & Variables & Estimate & $\begin{array}{c}\text { Standard } \\
\text { error }\end{array}$ & $\begin{array}{c}\mathbf{r}^{2} \text { ajusted } \\
(\%)\end{array}$ \\
\hline $\begin{array}{c}\text { Axis } \\
1\end{array}$ & $\begin{array}{l}\text { Constant } \\
\mathrm{pH}\end{array}$ & $\begin{array}{r}1510.99 \\
-1567.64\end{array}$ & $\begin{array}{c}197.98 \\
221.413\end{array}$ & $\begin{array}{c}0.00 \\
61.31\end{array}$ \\
\hline $\begin{array}{c}\text { Axis } \\
2\end{array}$ & $\begin{array}{l}\text { Constant } \\
\text { Suspended } \\
\text { solids }\end{array}$ & $\begin{array}{c}294.914 \\
-102.207\end{array}$ & $\begin{array}{l}64.6513 \\
36.1899\end{array}$ & $\begin{array}{c}0.00 \\
18.37\end{array}$ \\
\hline
\end{tabular}

Of all taxa found in the main channel, 157 were registered in the Upper Paraguay River and 98 in the Lower Paraguay River (Bray-Curtis index $=0.4$ ). In quantitative terms, the similarity was lower at high water $(0.24)$ than at low water (0.4).

\section{Floodplain of Paraguay River}

Zooplankton density (Fig. 6) in the floodplain was significantly higher at low water than at high water (MannWhitney $U$ test $=35 ; \mathrm{p}<0.05)$, with a maximum of 539 ind. $1^{-1}$ in the floodplain of the Cuiabá River (Fig. 6, site 56b). Rotifera was the most abundant taxa except during low water in two sites of the floodplain located farther from the main course (Fig. 6, sites 54b and 55b) where Copepoda nauplii were dominant. In floodplain lakes and streams, 91 taxa consisting of Rotifera (77), Cladocera (12) and Copepoda (2) were registered. Of these taxa, 77 were found in lakes and 58 in streams. At low water, species richness was at a maximum at the floodplain of the Cuiabá River, where 43 species were identified (Fig. 7, site 56). Species diversity fluctuated between

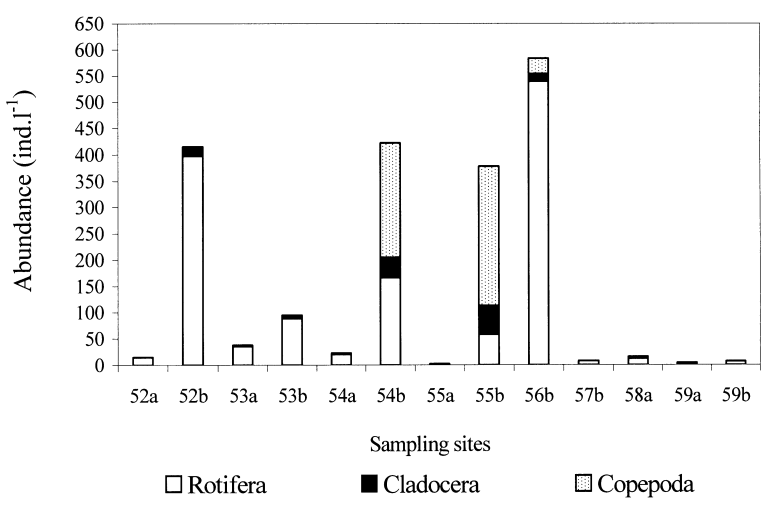

Fig. 6. Zooplankton abundance in upper and lower sections of Paraguay River floodplain at high (a) and low water (b).

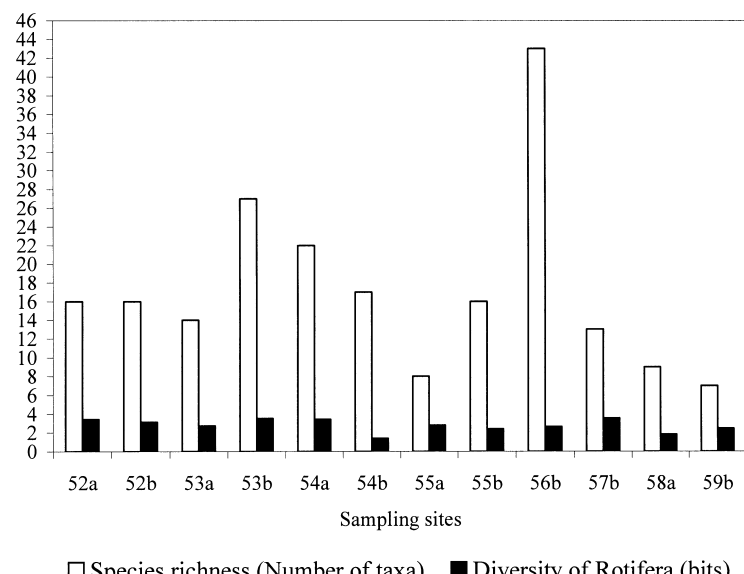

Fig.7. Species richness (Number of taxa) and diversity of Rotifera, Monogononta (bits) in upper and lower sections of Paraguay River floodplain at high (a) and low water (b).

ferences in species richness and diversity between hydrological phases were found in the floodplain. Different populations of Rotifera dominated in the floodplain, e.g. Keratella americana at site 52, Synchaeta sp. at site 53, Polyarthra at sites 54 and 58, Brachionus calyciflorus f. dorcas and f. amphyceros at site 59, and Polyarthra dolichoptera at site 56. Ceridaphnia cornuta, Bosmina (N.) hagmanni and Notodiaptomus coniferoides (Table 6) were the most abundant crustaceans in sites 54 and 55 .

\section{Discussion}

Our results show that zooplankton of the main course of the Paraguay River differ markedly between hydrological phases and that these differences are based on 
Table 6. The most frequent taxa of zooplankton in the Paraguay River and its floodplain. Hw = High water, Lw $=$ low water. Floodplain : S = Stream, $\mathrm{L}=$ lake.

\begin{tabular}{|c|c|c|c|}
\hline Taxa & $\begin{array}{c}\text { Upper } \\
\text { section }\end{array}$ & $\begin{array}{l}\text { Lower } \\
\text { section }\end{array}$ & Floodplain \\
\hline \multicolumn{4}{|l|}{$\overline{\text { PROTOZOA (Testacea) }}$} \\
\hline Arcella sp. & $\mathrm{Hw}$ & Hw & \\
\hline \multicolumn{4}{|l|}{ ROTIFERA } \\
\hline Bdelloidea & $\mathrm{Hw}$; Lw & $\mathrm{Hw} ; \mathrm{Lw}$ & $S ; \mathrm{L}$ \\
\hline B. caudatus Barrois \& Daday 1884 & $\mathrm{Hw}$; Lw & Lw & $S ; \mathrm{L}$ \\
\hline B. caudatus personatus Ahlstrom 1940 & $\mathrm{Hw}$; Lw & $\mathrm{Hw} ; \mathrm{Lw}$ & $\mathrm{L}$ \\
\hline B. calyciflorus f. amphyceros (Ehrenberg 1838) & & Lw & \\
\hline B. calyciflorus f. dorcas (Gosse 1851) & & $\mathrm{Lw}$ & \\
\hline B. falcatus Zacharias 1898 & Lw & Lw & $S ; \mathrm{L}$ \\
\hline B. mirus f. angustus (Koste 1972) & Lw & Lw & $\mathrm{L}$ \\
\hline C. coenobasis Skorikov 1914 & $\mathrm{Hw} ; \mathrm{Lw}$ & $\mathrm{Hw} ; \mathrm{Lw}$ & $\mathrm{S} ; \mathrm{L}$ \\
\hline Filinia saltator (Gosse 1886) & $\mathrm{Hw} ; \mathrm{Lw}$ & $\mathrm{Hw} ; \mathrm{Lw}$ & $\mathrm{S} ; \mathrm{L}$ \\
\hline F. terminalis (Plate 1886) & $\mathrm{Hw} ; \mathrm{Lw}$ & $\mathrm{Hw} ; \mathrm{Lw}$ & $\mathrm{S} ; \mathrm{L}$ \\
\hline F. longiseta (Ehrenberg 1834) & $\mathrm{Lw}$ & $\mathrm{Hw} ; \mathrm{Lw}$ & $\mathrm{S} ; \mathrm{L}$ \\
\hline F. opoliensis (Zacharias 1891) & $\mathrm{Hw}$; Lw & $\mathrm{Lw}$ & $\mathrm{L}$ \\
\hline Hexarthra intermedia Wieszniewski 1929 & $\mathrm{Hw}$; Lw & $\mathrm{Lw}$ & $\mathrm{S} ; \mathrm{L}$ \\
\hline Keratella americana Carlin 1943 & $\mathrm{Hw}$; Lw & $\mathrm{Hw} ; \mathrm{Lw}$ & $\mathrm{S} ; \mathrm{L}$ \\
\hline K. americana hispida (Lauterborn 1898) & $\mathrm{Lw}$ & Lw & $\mathrm{S} ; \mathrm{L}$ \\
\hline Keratella cochlearis Gosse 1851 & $\mathrm{Hw}$; Lw & $\mathrm{Hw} ; \mathrm{Lw}$ & $S ; \mathrm{L}$ \\
\hline K. tropica tropica (Apstein 1907) & Lw & $\mathrm{Hw} ; \mathrm{Lw}$ & $S ; \mathrm{L}$ \\
\hline L. proiecta Hauer 1956 & Lw & $\mathrm{Lw}$ & $\mathrm{L}$ \\
\hline Polyarthra spp. & $\mathrm{Hw}$; Lw & $\mathrm{Hw} ; \mathrm{Lw}$ & $S ; \mathrm{L}$ \\
\hline Synchaeta pectinata Ehrenberg 1832 & $\mathrm{Hw}$ & $\mathrm{Hw}$ & $\mathrm{S}$ \\
\hline Synchaeta sp. & $\mathrm{Hw} ; \mathrm{Lw}$ & $\mathrm{Hw} ; \mathrm{Lw}$ & $S ; \mathrm{L}$ \\
\hline Trichocerca spp. & $\mathrm{Hw} ; \mathrm{Lw}$ & $\mathrm{Hw} ; \mathrm{Lw}$ & S \\
\hline \multicolumn{4}{|l|}{ CLADOCERA } \\
\hline Bosminopsis sp. & Lw & $\mathrm{Hw} ; \mathrm{Lw}$ & S \\
\hline Bosminopsis deitersi Richard 1895 & $\mathrm{Hw} ; \mathrm{Lw}$ & $\mathrm{Hw}$ & $S ; \mathrm{L}$ \\
\hline Bosmina (N.) hagmani Stingelin 1904 & $\mathrm{Hw} ; \mathrm{Lw}$ & $\mathrm{Hw} ; \mathrm{Lw}$ & $\mathrm{S} ; \mathrm{L}$ \\
\hline Bosmina sp. & $\mathrm{Hw} ; \mathrm{Lw}$ & & $S ; \mathrm{L}$ \\
\hline Ceriodaphnia cornuta Sars 1886 & $\mathrm{Hw} ; \mathrm{Lw}$ & $\mathrm{Hw} ; \mathrm{Lw}$ & $\mathrm{L}$ \\
\hline Diaphanosoma sp. & $\mathrm{Hw} ; \mathrm{Lw}$ & $\mathrm{Hw} ; \mathrm{Lw}$ & $S ; L$ \\
\hline Moina minuta Hansen 1899 & $\mathrm{Hw} ; \mathrm{Lw}$ & $\mathrm{Lw}$ & $\mathrm{L}$ \\
\hline \multicolumn{4}{|l|}{ COPEPODA } \\
\hline Eucyclops sp. & & $\mathrm{Hw}$ & \\
\hline Thermocyclops sp. & $\mathrm{Hw}$ & & \\
\hline Notodiaptomus coniferoides (Wright 1927) & Lw & & $\mathrm{L}$ \\
\hline Notodiaptomus santafesinus Ringuelet \& Martinez de Ferrato 1967 & & Lw & \\
\hline Notodiaptomus sp. & Lw & & S \\
\hline Parastenoscaris dentata Dussart 1979 & $\mathrm{Hw}$ & & \\
\hline Potamoscaris bifida Dussart 1979 & $\mathrm{Hw}$ & & \\
\hline
\end{tabular}




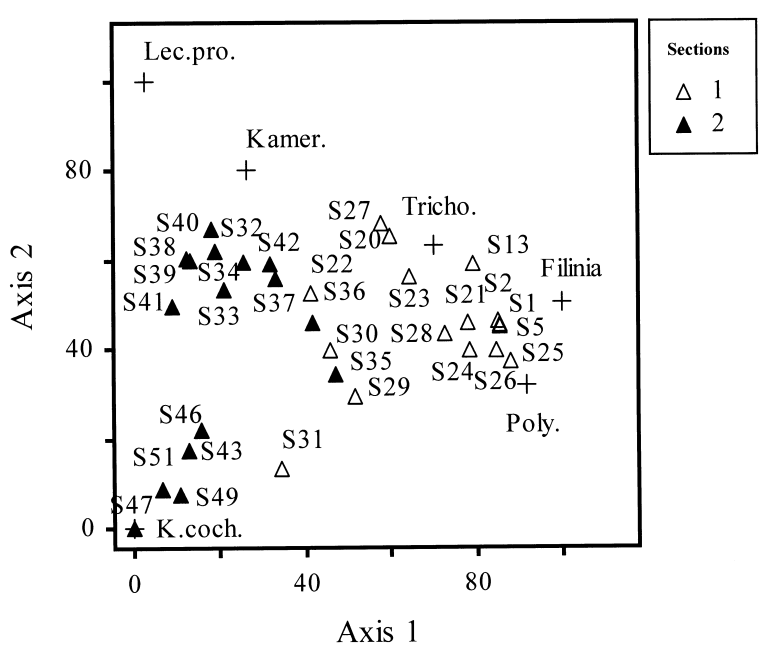

Fig. 8. Dentrended Correspondence Analysis ordination plot of site scores on the 1 and 2 axes at low water of Paraguay River. Upper section 1 : dark triangles. Lower section 2 : open triangles.

abundance, species richness and species diversity (Rotifera). The observed abundances were similar to those found in other floodplain rivers of tropical and subtropical South America (Corrales 1979, José de Paggi 1984, Bonetto \& Corrales de Jacobo 1985, Vásquez \& Rey 1989, Paggi \& José de Paggi 1990, Ibañez et al. 2004). Higher concentrations of zooplankton were observed at low water as noted previously in the Upper and Lower Paraná River (Corrales 1979, Bonetto \& Corrales de Jacobo 1985, José de Paggi 1988, Paggi \& José de Paggi 1990) and in the Orinoco River (Saunders \& Lewis 1989, Vásquez \& Rey 1989). These variations were attributed to changes in runoff, current velocity, and turbidity, which are the main factors influencing zooplankton abundance in rivers (Pourriot et al. 1982, Armengol et al. 1983, Margalef 1983, Saunders \& Lewis 1988 b, Paggi \& José de Paggi 1990, Thorp et al. 1994, Frutos 1998, Gulyas 2002). However, upstream of Porto Cáceres (Upper Paraguay River) the highest density of zooplankton at high water could be caused by a combination of low current velocity, high temperatures, low concentrations of suspended solids and high phytoplankton density, with Chlorophyta predominanting (Zalocar de Domitrovic 2002). Several studies have demonstrated that these variables may have favored zooplankton abundance (Pourriot et al. 1982, Paggi \& José de Paggi 1990, Pace et al. 1992, Gudrun et al. 1994, Thorp et al. 1994, Basu \& Pick 1996, Frutos 1998).
As observed in the Paraná River (José de Paggi 1993), water level fluctuations affect rotifer density in the floodplain of the Paraguay River. Large cladocerans, which are abundant in lagoons and channels of the Upper Paraná during low water (Lansac Tôha et al. 2004), were conspicuously scarce from our samples taken in the floodplain. Although there is little information concerning planktivorous fish in the Paraguay River, selective predation on cladocerans by both invertebrates and vertebrates may increase mortality in cladocerans (Matveev et al. 1989, Hamilton et al. 1990, Matveev et al. 1992).Abundances of Rotifera have been reported in several studies of tropical, subtropical (Corrales 1979, José de Paggi 1980, Robertson \& Hardy 1984, Shiel 1985, Bonetto \& Corrales de Jacobo 1985, Saunders \& Lewis 1988 a and b, Vásquez \& Rey 1989, Lanzac Tôha et al. 2004) and temperate rivers (Pace et al. 1992, Gudrun et al. 1994, Thorp et al. 1994). Rotifera may dominante other taxa because they are opportunists with a short generation time (Rzóska 1976, Pourriot et al. 1982, Gulyas 2002, Lanzac Tôha et al. 2004), and are better adapted to turbulence and high concentrations of suspended solids (Armengol et al. 1983, Bonetto \& Corrales de Jacobo 1985, Kirck \& Gilbert 1990, Paggi \& José de Paggi 1990). The dominance of Protozoa (Testacea) in some sites of the Upper Paraguay is probably related to particularities of these sites which have vegetated areas with Eichhornia azurea and slow flow (Poi de Neiff 2003). Lansac Tôha et al. (2004) found a high abundance of thecamoebas in vegetated areas of the Upper Paraná River in a lentic habitat of the floodplain. Species of Copepoda registered in the Upper Paraguay were characteristic of large floodplain rivers (Dussart 1979, 1983, Dussart \& Frutos 1985, 1986).

Considering all study sites (main course and its floodplain), species richness in the Paraguay River was 196, which was lower than that reported for other SouthAmerican rivers (Robertson \& Hardy 1984, Bonetto \& Corrales de Jacobo 1985, Vásquez \& Rey 1989, Paggi \& José de Paggi 1990, Lansac Tôha et al. 2004). Our study provided a preliminary description of zooplankton diversity because we sampled most sites for only two hydrological phases, which is probably insufficient given the large internal variability in hydrology in the region (Hamilton et al. 1996).

Species richness was the highest in some sites of the floodplain habitat. However, the total number of taxa was higher in the main channel than in the floodplain. This could be an effect of the unbalanced number of samples, with 8 taken from the floodplain and 51 from the main channel. The large numbers of species in both habitats (81) indicate the importance of the connection between 
the main course and the floodplain through different tributaries. The high number of tichoplanktonic species evidences their incorporation of the vegetated areas located in the proximal floodplain. In spite of the high number of identified species, few species are as important numerically as in other South American rivers (José de Paggi 1980, Paggi 1980, José de Paggi 1981, Bonetto \& Corrales de Jacobo 1985, Vásquez \& Rey 1989).

The absence of a well-defined longitudinal pattern of abundance at high water is consistent with the observation of Vásquez \& Rey (1989) for the Orinoco River. However, in this river, Saunders \& Lewis (1989) found that average rotifer and copepod densities tended to decrease downstream and that there were no uniform longitudinal trends for cladocerans in the main channel. At low water, the ordination of the species-sites along the gradient was related to $\mathrm{pH}$ and suspended solids concentration. This variable strongly influences the composition and abundance of zooplankton (Bonetto \& Corrales de Jacobo 1985, Paggi \& José de Paggi 1990, Frutos 1998, Ibañez et al. 2004). K. cochlearis tolerates a large range of $\mathrm{pH}$ and suspended solids concentrations whereas L. proiecta is adapted to high suspended solids concentrations (José de Paggi 1994). Downstream of the Bermejo River, the $69 \%$ increase in the concentration of suspended solids produced a simultaneous decrease in phytoplankton (Zalocar de Domitrovic 2002) and zooplankton abundance.

The same cosmopolitan taxa that dominate the main course of the Paraguay River (Polyarthra, K. americana, K. cochlearis, Lecane proiecta, Filinia and Trichocerca), were found to dominate in other large South American Rivers (José de Paggi, 1980, 1981, Bonetto \& Corrales de Jacobo 1985, Saunders \& Lewis 1989). In addition, the observed association between K. americana and Lecane proiecta was reported for the Orinoco River during the low water phase (Vásquez \& Rey 1989).

The main feature of the Paraguay River is the high spatial heterogeneity due to the hydrochemistry of the water courses flowing into the main course at low water. As with phytoplankton (Zalocar de Domitrovic 2002), environmental discontinuities affect the distribution and abundance of zooplankton of the Paraguay River, where no longitudinal gradient from the head to mouth was found at high water. The pulsing of the river determines the degree of connectivity with the floodplain and local features had a greater effect on zooplankton assemblages than large-scale landscape patterns. The great total number of taxa and the high local species diversity in the upper section can be attributed to the presence of a larger tropical wetland system (Neiff 1990).

\section{Acknowledgements}

The authors would like to thank Dr. Susana José de Paggi and Dr. Juan C. Paggi for the identification of dominant zooplankton. This work was supported by grants PICT 07-12755 and PIP 6316 from the ANCYPT - CONICET, Argentina. We thank the anonymous reviewers who provided useful comments on the manuscript.

\section{References}

Adamoli J. \& Pott A. 1999. - Las fuentes de diversidad en el Pantanal. Pages 317-360 in Biodiversidad y uso de la tierra. Conceptos y ejemplos de Latinoamérica. Matteucci S.D., Solbrig O.T., Morello J. \& Halffer, G. (eds). Eudeba, Buenos Aires.

Armengol J., Moreau G. \& Planas D. 1983. - Évolution, à court terme, des commnunautés zooplanctoniques de deux rivières du nord Québécois soumises à une forte réduction de débit. Can. J. Zool., 61, 2011-2020.

Basu, B.K. \& Pick F.R. 1996. - Factor regulating phytoplankton and zooplankton biomass in temperate rivers. Limnol. Oceanogr., 41, 1572-1577.

Bezerra M.A.O., Miranda J.C.A., Ferreira C.J.A., Ishii I.H. \& Moreno I.H. 1996. - Estudo da comunidade zoplanctônica da Bacia do rio Miranda. (Mato Grosso do Sul). Pages 237-248 in II Simpósio Sobre Recursos Naturais e Sócio-econômicos do Pantanal : Manejo e Conservaçao. EMBRAPA/UFMS, Corumbá.

Bonecker C.C., Lansac-Tôha F.A. \& Bini L.M. 1996. Composition of zooplankton in different environments of the Mato Grosso Pantanal. Mato Grosso do Sul. Anais do VIII seminario Regional de Ecologia, 3, 1123-1135.

Bonetto A.A. \& Corrales de Jacobo M.A. 1985. - Zooplancton del río Paraná Medio : Variaciones temporales y distribucionales en el área de confluencia con el río Paraguay. Ecosur, 5, 1-23.

Bonetto A.A. 1986. - The Paraná River System. Pages 541-555 in Ecology of River Systems. Davies B.R. \& Walker K.F. (eds), Junk Publ., Dordrecht.

Bray J.R. \& Curtis C.T. 1957. An ordination of the upland forest communities of sourthern Wisconsin. Ecol. Monogr., 27, 325-49.

Corrales M.A. 1979. Contribución al conocimiento del zooplancton del río Alto Paraná. Ecosur, 6, 185-205.

Drago E. 1990. - Geomorphology of large alluvial rivers : lower Paraguay and Middle Paraná. Interciencia, 15, 378-387.

Dussart B.H. 1979. - Algunos Copépodos de América del Sur. Santiago de Chile. Mus. Nac. Hist. Nat., 30, 1-13.

Dussart B.H. 1983. - Sobre algunos Copépodos de América del Sur III. CONICET. In the Comunicaciones Científicas del Centro de Ecología Aplicada del Litoral, Corrientes, 16, 1-8.

Dussart B.H. \& Frutos S.M. 1985. - Sur quelques Copépodes d'Argentine, Rev. Hydrobiol. Trop., 18, 305-314.

Dussart B.H. \& Frutos S.M. 1986. - Sur quelques Copépodes d'Argentine, 2. Copépodes du Paraná Medio. Rev. Hidrobiol. trop., 19, 241-262.

Espíndola E.G., Matsumura-Tundisi T., Moreno I.H. 1996. - Efeitos da Dinâmica Hidrológica do Sistema Pantanal Matogrossense Sobre a Estrutura das Comunidades de Zooplâncton da Lagoa Albuquerque. Acta Limnol. Bras., 8, 37-57.

Frutos S.M. 1993. - Zooplancton en cuerpos de agua isleños del Bajo Paraná. Ambiente Subtropical, 3, 87-121.

Frutos S.M. 1996. - Zooplancton de la laguna Turbia (Isla del Cerrito) en la confluencia de los ríos Paraná y Paraguay (Argentina). Rev. Bras. Biol., 56, 569-580.

Frutos S.M. 1998. - Densidad y diversidad del zooplancton en los ríos Salado y Negro. Planicie del río Paraná. Argentina. Rev. Brasil. Biol., 58, 431-444. 
Gudrun H., Hein T. \& Schiemer F. 1994. - The significance of hydrological connectivity for limnological processes in Danubian backwaters. Verh. Internat.Verein. Limnol., 25, 1674-1679.

Gulyas P. 2002. - Zooplankton. Pages 123-137 in Joint Danube Survey. Literáthy, P. Koller-Kreimel, V. \& Liska I. (eds).Technical Report of the International Commission for the Protection of the Danube River. Viena.

Hamilton S.K., Sippel S.J., Lewis Jr. W.M \& Saunders III J.F. 1990. - Zooplankton abundance and evidence for its reduction by macrophyte mats in two Orinoco floodplain lakes. Journal of Plankton Research, 12, 345-363.

Hamilton S.K., Sippel S.S.J., Calheiros D.F. \& Melack J.M. 1996. Chemical characteristics of pantanal waters. Anais do II Simpósio sobre Recursos Naturais e Sócio-econômicos do Pantanal, Embrapa, Corumbá, 89-100.

Hamilton S.K., Sippel S.S.J., Calheiros D.F. \& Melack J.M. 1997. An anoxic event and other biogeochemical effects of the Pantanal Wetland on the Paraguay River, Limnol. Oceanogr., 42, 257-272.

Ibañez, C., Paggi J.C., Molina C., Pinto J. \& Koste W. 2004. Zooplancton de las lagunas. Pages 272-299 in Diversidad biológica en la llanura de inundación del Río Mamoré. Importancia ecológica de la dinámica fluvial. Pouilly M., Beck S.G., Moraes R.M. \& Ibañez C. (eds). Funadación Simón I. Patiño, Santa Cruz.

José de Paggi S. 1980. - Campaña limnológica Keratella I en el río Paraná Medio : zooplancton de ambientes lóticos. Ecología, 4, 69-75.

José de Paggi S. 1981. - Variaciones temporales y distribución horizontal del zooplancton en algunos cauces secundarios en el río Paraná Medio. Stud. Neotrop. Fauna, 16, 185-189.

José de Paggi S. 1984. - Estudios limnológicos en una sección transversal del tramo medio del río Paraná: distribución estacional del zooplancton. Rev. Asoc. Nat. Litoral, 15, 135-155.

José de Paggi S. 1988. - Estudio sinóptico del zooplancton de los principales cauces y tributarios del valle aluvial del río Paraná : tramo Goya-Diamante (II). Stud. Neotrop. Fauna, 23, 149-163.

José de Paggi S. 1993. - Composition and seasonality of planktonic rotifers in limnetic and littoral regions of a floodplain lake (Paraná river system). Rev. Hydrobiol. trop., 26, 53-63.

José de Paggi S. 1994. - Zooplancton del Río Paraná: Microcrustáceos y Material Inorgánico en Suspensión. Master Thesis, Universidad Nacional del Litoral, Santa Fe, 66 p.

Kirk K.L. \& J.J. Gilbert 1990. - Suspended clay and the population dynamics of planktonic rotifers and cladocerans. Ecology, 7, 1741-1755.

Lansac Tôha F.A., Bonecker L., Velho C.C. \& Machado Velho L.F. 2004. - Composition, species richness and abundance of the zooplankton community. Pages 145-190 in The Upper Paraná and its floodplain. Fisical aspects, ecology and conservation. S.M. Thomaz A.A., Agostinho and N.S. Hahn. (eds).Backhuys Publishers, Leinden.

Maamri A., Pattee E., Doledec S. \& Chergui H. 2005 - The benthic macroinvertebrate assemblages in the Zegzel-Cherraa, a partlytemporary river system, Eastern Morocco. Ann. Limnol. - Int. J. Lim., 41, 247-257

Margalef R. 1983. - Limnología. Ediciones Omega, Barcelona, $1010 \mathrm{p}$.

Matveev V.F., Martinez, C.C. \& Frutos S.M. 1989. - Predatory-prey relationships in subtropical zooplankton: water mite against cladocerans in an Argentine lake. Oecologia, 79, 489-495.

Matveev V.F., Martinez C.C., Frutos S.M. \& Zalocar de Domitrovic Y. 1992. - Population control in planktonic crustaceans of a subtropical lake during seasonal succession. Arch. Hydrobiol., 124, 1-18.
McCune B. \& Mefford M.J. 1997. - PC-ORD. Multivariate analyses of ecological data. Gleneden Beach, Oregon, MjM Software.

Meyer J.L. \& Edwards R.T. 1990. - Ecosystem metabolism and turnover of organic carbon along a blackwater river continuum. Ecology, 71, 668-677.

Minshall G.W., Cummins K.W., Petersen R.C., Cushing C.E., Bruns D.A., Sedell J.R. \& Vannote R.L. 1985. - Developments in stream Ecosystem Theory. Can. J. Fish. Aquat. Sci., 42, 10451054.

Miranda L. \& Raborn S. 2000. -From zonation to connectivity : fluvial ecology paradigms of the $20^{\text {th }}$ century. Pol. Arch. Hydrobiol., 47, 5-19.

Neiff J.J. 1990. - Ideas para la interpretación ecológica del Paraná. Interciencia, 15, 424-441.

Neves I.F., Rocha O., Roche K.F. \& Pinto A.A. 2003. Zooplankton Community Structure of Two Marginal Lakes of the River Cuiabá (Mato Grosso, Brazil) with Analysis of Rotifera and Cladocera Diversity. Braz. J. Biol., 63, 329-343.

Orfeo O. 1995. - Sedimentología del Río Paraná en el área de confluencia con el río Paraguay. Tesis Doctoral, Facultad de Ciencias Naturales y Museo, Universidad Nacional de La Plata, La Plata, 289 p.

Pace M.L., Stuart E.G. \& Lints D. 1992. - Zooplankton in Advective Environments : The Hudson River Community and a Comparative Analysis. Can. J. Fish. Aquat. Sci., 49, 1060-1069.

Paggi J.C. 1980. - Campaña Limnológica "Keratella I" en el río Paraná Medio (Argentina) : Zoopláncton de ambientes leníticos. Ecología, 4, 77-88.

Paggi J.C. \& José de Paggi S.B. 1990. - Zooplankton of the lotic and lentic environments of the middle Paraná River. Acta Limnol. Brazil., 3, 685-719.

Petts G. \& Calow P. 1996. - River Biota. Diversity and dynamics. Blackwell. London, $257 \mathrm{p}$.

Poi de Neiff A. 2003. Macroinvertebrates living on Eichhornia azurea Kunth In the Parguay River. Acta Limnol. Brasil., 15, 1-8.

Pourriot R., Benest D., Champ P. \& Rougier C. 1982. - Influence de quelques facteurs du milieux sur la composition et dynamique saisonniere du zooplancton de la Loire. Acta Oecol. Gener., 3, 353-371.

Reid J.W. \& Moreno I.H. 1990. The Copepoda (Crustacea) of the Southearn Pantanal, Brazil. Acta Limnol. Brasil., 3, 72-740.

Robertson B.A. \& Hardy E.R. 1984. - Zooplankton of Amazonian lakes and rivers. Pages 337-352 in The Amazon: Limnology and landscape ecology of a mighty tropical river and its basin. Sioli H. (ed), Junk Publ., The Hague.

Rzózka J. 1976. - Zooplankton of the Nile System. Pages 333-344 in The Nile, Biology of Ancient River. Rzózka J. (ed), Junk Publ., The Hague.

Saunders J.F. \& Lewis W. 1988 a. - Zooplankton abundance and transport in a tropical white-water river. Hydrobiologia, 162, 147155.

Saunders J.F. \& Lewis W. 1988 b. - Zooplankton abundance in the Caura River, Venezuela. Biotropica, 20, 206-214.

Saunders J.F. \& Lewis W. 1989. - Zooplankton en the Lower Orinoco River, Venezuela. Limnol. Oceanogr., 34, 397-409.

Shannon C. \& Weaver W. 1963. - The mathematical theory of communication. Illinois University Press, Urbana, $177 \mathrm{p}$.

Shiel R.J. 1985. - Zooplankton of the Darling system, Australia. Verh. Int. Ver. Limnol., 22, 2136-2140.

Statzner B. \& Higler B. 1985. - Questions and comments on the River Continuum Concept. Can. J. Fish. Aquat. Sci., 42, 10381044.

Thorp J.H., Black A.R., Haag K.H. \& Wehr J.D. 1994. Zooplankton Assemblages in the Ohio River: Seasonal, 
Tributary, and Navigation Dam Effects. Can. J. Fish. Aquat. Sci., $51,1634-1643$.

Vannote R.L., Minshall G.W., Cummins K.W., Sedell J.R. \& Cushing C.E. 1980. The rivers continuum concept. Can. J. Fish. Aquat. Sci., 37, 130-137.

Vásquez E. \& Rey J. 1989. - A longitudinal study of zooplankton along the lower Orinoco River and its Delta (Venezuela). Ann. Limnol., 25, 107-120.

Welcomme R.L. 1992. - Fisheries ecology of floodplain rivers. Longman, London, 317 p.
Wiley M.J., Osborne L.L. \& Larimore R.W. 1990. - Longitudinal structure of an agricultural prairie system and its relationship to current stream ecosystem theory. Can. J. Fish. Aquat. Sci., 47, 373-384.

Zalocar de Domitrovic Y. 2002. - Structure and variation of the Paraguay River phytoplankton in two periods of its hydrological cycle. Hyrobiologia. Kluwer Academic Publishers. The Netherlans. 472, 177-196.

Zar, J.H. 1984. Biostatistical análisis. - (2da. Ed.) Prentice-Hall, Englewood Cliffs, New Jersey, 718 p. 